УДК 371.3:51

DOI:

Людмила Силюга, кандидат фізико-математичних наук, дочент кафедри математики, інформатики та методики їх викладання у початковій иколі Дрогобииького державного педагогічного університету імені Івана Франка

Тетяна Волошин, магістр факультету початкової та мистецької освіти Дрогобииького державного педагогічного університету імені Івана Франка

\title{
СИСТЕМА ПРИКЛАДНИХ ЗАДАЧ ЯК ЗАСІБ ФОРМУВАННЯ ПІЗНАВАЛЬНОӤ АКТИВНОСТІ МОЛОДШИХ ШКОЛЯРІВ
}

У статті досліджується одна з найбільш актуальних проблем особистісноорієнтованої педагогіки формування пізнавальної активності учнів початкових класів. Розглядається сутність понять "пізнавальна активність" та "прикладна задача". Розкриваються особливості розвитку пізнавальної активності молодших школярів під час розв 'язування прикладних задач. С формульовані основні критерії підготовленості учнів до розв 'язування прикладної задачі. Визначені основні вимоги до прикладних задач, які використовуються у навчанні молодших школярів математики з метою підвищення їх пізнавальної активності.

Ключові слова: пізнавальна активність; молодші школярі; початкова школа; навчальний процес; математика; система прикладних задач.

Jim. 7.

Lyudmyla Sylyuha, Ph.D. (Physics and Mathematics), Associate Professor of the of the Mathematics, Informatics and

Methods of Teaching in Primary School Department

Drohobych Ivan Franko State Pedagogical University Tetiana Voloshyn, Master of the Faculty of Primary and Art Education Drohobych Ivan Franko State Pedagogical University

\section{SYSTEM OF APPLIED PROBLEMS AS A MEANS OF FORMATION OF COGNITIVE ACTIVITY OF PRIMARY SCHOOL PUPILS}

In the article one of the most pressing problems of personality-oriented pedagogy - the formation of cognitive activity of the pupils of primary school is invistigated.

The article consideres the theoretical and methodological foundations of formation of cognitive activity of primary school pupils "applied problem". The peculiarities of the development of cognitive activity of primary school pupils at solving of applied problems are revealed. The main criteria for preparing pupils to solve the applied problem are formulated. The basic requirements to the applied problems which are used at studying of pupils of mathematics for the purpose of increase of their cognitive activity are defined.

The problem of development of cognitive activity is one of the cardinal problems not only of didactics, but also of all educational process, because its solution will help to solve other issues: training of pupils to thinking, development of cognitive interests, formation of independence, creativity, determination of mental abilities, and also acquisition of such qualities as observation, determination, responsibility, etc.

One of the methodological requirements for the implementation of the applied orientation of the initial course of mathematics is the filling of the educational process of applied problems. These are problems that arose outside of mathematics, but are solved by mathematical means. Such problems satisfy the following methodological requirements:

1) the problems must have a real practical content, which provides an illustration of the practical value and significance of the acquired mathematical knowledge;

2) the problems must correspond to school programs and current textbooks of mathematics as to the methods and facts that will be used in the process of solving them;

3) the content of the problem should arouse the pupils' cognitive interest, give the opportunity to demonstrate the effective use of mathematical knowledge in practice;

4) concepts and terms of tasks should be known or understandable for pupils,

5) numerical data of applied problems must correspond to those that exist in practice, that is to be real, which does not lead to cumbersome calculations.

Only by complying with such requirements the teacher will be able to show pupils that mathematics reflects the world around them, that numbers, actions, mathematical terminology have a real meaning. It will 


\section{СИСТЕМА ПРИКЛАДНИХ ЗАДАЧ ЯК ЗАСІБ ФОРМУВАННЯ ПІЗНАВАЛЬНОЇ АКТИВНОСТІ МОЛОДШИХ ШКОЛЯРІВ}

not be the formal study of the subject, it will teach pupils to see in mathematics a way to solve of practice life issues. problems.

Keywords: cognitive activity; junior students; primary school; the educational process; system of applied

П

остановка проблеми. Одним is основних напрямів сучасної освіти є формування практично компетентної особистості, яка володіла б уміннями моделювати реальні процеси та явища, зокрема економічно-фінансові, аналізувати і порівнювати дані, прораховувати ризики, інтерпретувати результати, працювати зі знако-символьним представленням інформації тощо. Тому формування в учнів пізнавальної активності $\epsilon$ одним із першочергових завдань школи.

Основними напрямами підвищення в учнів рівня їх пізнавальної активності є посилення практичної і прикладної спрямованості шкільного курсу математики. Практична спрямованість означає навчання безпосередньо застосовувати знання, які отримали учні під час вивчення теоретичного курсу математики, формувати обчислювальних умінь та навиків, виконувати тотожні перетворення, розв'язувати рівняння, нерівності, сюжетні задачі, геометричні задачі на побудову, обчислення, доведення та дослідження. Прикладна спрямованість передбачає вироблення в учнів умінь використовувати здобуті під час вивчення математики знання у практичній діяльності та при вивченні інших навчальних дисциплін. Тому навчання математики у початкових класах необхідно пов'язувати 3 першими кроками у практичній підготовці учнів до оволодіння ними знаннями, вміннями i навичками, які є необхідні в майбутньому людині будь-якої професїі.

У розв'язанні цього важливого методичного питання вчителям початкових класів допомагає система прикладних задач, метою якої $\epsilon$ різноплановість, збудження інтересу, ілюстрація застосування математики в житті. Найбільшого значення у змістовому компоненті набуває система пізнавальних завдань прикладного змісту, що має випереджувальний характер у порівнянні 3 досягнутим рівнем розвитку учнів.

Аналіз основних досліджень і публікацій. Проблема формування пізнавальної активності особистості постає у центрі уваги багатьох вчених. Різні аспекти зазначеної проблеми $\epsilon$ предметам педагогічних та психологічних досліджень. Так, у студіях науковців розкривається сутність поняття "пізнавальна активність” (Н. Редьковець, І. Харламов, С. Хилько [7], Т. Шамова); аналізуються особливості формування пізнавальної активності та пізнавальних інтересів на різних етапах розвитку особистості (Н. Бібік, Д. Богоявленський, Л. Данилова [1], О. Киричук, В. Лозова [2]). Проблему активізації навчально-пізнавальної діяльності учнів досліджували М. Богданович, В. Паламарчук, О. Савченко [5], О. Скрипченко, М. Стельмахович та інші. М. Федорова розглядає пізнавальну активність як складову формування моральних цінностей в учнів початкових класів [6]. Питанням використання навчальної гри як засобу активізації пізнавальної діяльності на уроках у початкових класах займається Л. Романенко [4].

Мета статті. Головною метою роботи $\epsilon$ визначення основних методичних підходів до формування пізнавальної активності учнів початкових класів у процесі розв'язування прикладних задач.

Виклад основного матеріалу. Розвивальна функція навчання математики є важливим принципом нової концепції математичної освіти, оскільки основою методики навчання математиці стає не вивчення основ математичної науки, а пізнання дитиною навколишнього світу засобами математики. 3 психологічної точки зору пізнавальна активність - це міра розумового зусилля, спрямована на задоволення пізнавальних інтересів індивіда. Як педагогічне явище, пізнавальна активність є двостороннім взаємопов'язаним процесом: 3 одного боку, це форма самоорганізації і самореалізації учня, 3 іншого - результат цілеспрямованих зусиль педагога в організацї пізнавальної діяльності учня.

Пізнавальна активність не дає змогу молодшому школяреві “топтатися” на місці, бути залежним, чекати, поки хтось допоможе, покаже, розв'язати за нього. Вона “штовхає” дитину до певних самостійних дій: запитати, відшукати певну інформацію, прочитати, написати, зробити. Формування пізнавальної активності молодших школярів 3 математики починається 3 виховання у них пізнавальної потреби, розвиток якої відбувається чотирма етапами:

1) зацікавлення емпіричною і основою навчання (яскраві ілюстрації, цікаві факти, незвичайні ситуації, ігрові моменти тощо);

2) виникнення допитливості, бажання дізнатися про певні якості предмета;

3) виділення об'єкта вивчення, спрямування інтересу на його дослідження; 


\section{СИСТЕМА ПРИКЛАДНИХ ЗАДАЧ ЯК ЗАСІБ ФОРМУВАННЯ ПШЗНАВАЛЬНОЇ АКТИВНОСТІ МОЛОДШИХШКОЛЯРІВ}

4) захоплення улюбленим предметом, творчою
роботою [1].
У класоводів виникають труднощі, коли
доводиться визначати рівень пізнавальної
активності учнів 3 математики. Сумарним
показником тут є їхн навченість. Важливий
складник навченості з математики - це розвинуте
функціональне мислення, за якого учні чітко
уявляють математичні об'єкти в динаміці, вправно
оперують математичними фактами, встановлюючи
причиново-наслідкові зв’язки, вміють застосовувати
математичні знання на практиці.

Вивчаючи математику у школі, учням часто доводиться розв'язувати сюжетні задачі за різноманітною тематикою: фізичні, хімічні, економічні, побутові та інші. Спостерігаючи за роботою учнів, бачимо, що інтерес до розв'язування сюжетних задач у них зростає, коли фабули їх стосуються виробничо-життєвого змісту, а метою роботи є навчання способу застосування математичних знань для початкового вивчення явищ природи, виробництва. Такі задачі описують проблему і містять нематематичні поняття, але їх можна перекласти на мову математики за допомогою рівнянь, таблиць, схем тощо. Це прикладні задачі, які можна розв'язати 3 застосуванням досягнень математики. Саме такі задачі дають можливість показати тісний зв'язок теорії з практикою, а саме: математичні абстракції виникають із задач, поставлених реальним життям [3].

Прикладні задачі - це задачі, які виходять за межі математики, але розв'язуються математичними методами і засобами. Прикладними задачами в математиці називають такі, умови яких містять нематематичні поняття.

Прикладні задачі виконують різні дидактичні цілі, основними з яких є:

- навчальна (формування знань, навичок і вмінь на різних етапах засвоєння навчального матеріалу 3 математики);

- виховна (формування наукового світогляду, пізнавального інтересу і самостійності, моральних якостей учнів);

- розвивальна (розвиток логічного мислення, оволодіння загальними та специфічними розумовими діями та ефективними прийомами розумової діяльності).

Розв'язуючи прикладні задачі пізнавального характеру, учні оволодівають не лише обчислювальними навичками, арифметичними діями, а й ознайомлюються 3 різноманітністю навколишнього світу: явищами природи, тваринним і рослинним світом, історією, досягненнями науки і культури.
Прикладні задачі руйнують стандартність мислення постійним залученням учнів до аналізу початкової інформації та прогнозування одержаних результатів. Основним же вважається залучення самих учнів при роботі з інформацією до створення орієнтованої основи, яка із самого початку зміщує акценти освітнього процесу з необхідності запам'ятовувати на необхідність уміння застосовувати інформацію і тим самим сприяє переходу учнів з рівня репродуктивного засвоєння на дослідницький. Включення прикладних задач до освітнього процесу сприяє розвитку у школярів прийомів дослідницької роботи, побудови математичних моделей, а також формування грамотності учнів у представленні результатів своєї праці.

Для свідомого засвоєння змісту прикладних задач основне - зрозуміти оточення, 3 якого їх узято, обставини, за яких доводиться у житті їх розв'язувати. Без цього дітям важко встановити і зрозуміти залежність між величинами, вказати, яким чином можна знайти відповідь.

Більшість прикладних задач доцільно складати під час практичних занять 3 вимірювання. Ознайомлюючи дітей з новими одиницями маси, довжини, часу, площі тощо, вчитель має змогу урізноманітнювати завдання, допомагати у спостереженнях за природою і трудовими процесами.

Серед всіх видів прикладних задач ми розглядаємо ті, в яких ситуація насправді реальна для молодшого школяра, практично важлива i служить навчальним цілям. У фабулах таких задач говориться про виробничі або життєві ситуації, при розв'язуванні яких застосовуються знання, вміння і навички. Зміст таких задач має бути різноманітним і відображати промисловість, сільське господарство, транспорт, зв'язок, культуру і освіту, охорону здоров'я, побут. Крім того, він має бути доступним для розуміння, чітко сформульованим, технічно грамотно побудований. Запитання у задачах прикладного змісту мають бути цікавими й реальними. Їх не можна грубо округлювати. Наведемо приклади деяких прикладних задач пізнавального змісту, які вчитель може використовувати на уроках математики у початкових класах:

Задача 1. Годівнички для птахів розвішують найнижче - на 4м і найвище - на 8м. Тато повісив годівничку на висоті 5м. Чи правильно він вчинив?

Задача 2. Шоколадка коштує 30 грн. В супермаркеті протягом місяця діє спеціальна пропозиція: купуючи дві шоколадки, отримуєш три (одна в подарунок). Скільки шоколадок можна придбати на 180 грн в цей місяць? 
Задача 3. Водопровідний кран погано закри-тий. Кожну секунду з нього капає лише одна крапля. Чи багато витече 3 нього води за 1год (за 1 добу), якщо маса 100 крапель дорівнює 7г?

Задача 4. Для засолювання помідорів беруть 200г солі на 2л води. Чи вистачить 800 г солі для приготування 9л такого розсолу?

Задача 5. Мені купили акваріум у формі куба, який вміщує 64л води. Я наповнив акваріум водою, не доливши 5 см до верхнього краю. Яку найбільшу кількість рибок я можу запустити, якщо для 4 рибок треба 10л води?

Для того щоб у школярів сформувалися уміння розв'язувати прикладну задачу, вчителю необхідно навчити їх:

- виділяти суттєві факти досліджуваного явища (процесу);

- визначати основні взаємозв'язки між даними і шуканими задачі;

- аналізувати умову задачі;

- обирати математичний апарат для побудови моделі.

Важливу роль у посиленні практичного спрямування курсу математики відіграє формування у молодших школярів уявлень про загальність математичних знань, про те, зокрема, що різні прикладні задачі можна розв'язувати одним і тим самим способом, складати обчислювати одні і ті самі вирази, які є розв'язком задачі, а також одну і ту саму задачу можна розв’язувати декількома способами і шукати серед них найоптимальніший.

Висновки і пропозиції. Дані нашого дослідження дали підставу сформулювати основні вимоги до прикладних задач, які використовуються у навчанні молодших школярів математики з метою підвищення їх пізнавальної активності:

- зміст задачі має бути доступним для розуміння учням, відповідати рівню розвитку, пізнавальним можливостям та інтересам молодших школярів;

- шукані і дані в задачі величини повинні бути реальними, взяті з навколишньої практики;

- формулювання запитання задачі повинно бути близьким до того, як воно ставиться у практиці; фабула і застосовувана термінологія задачі не повинні ускладнювати ії математичний зміст;

- прийоми і методи розв'язування задач повинні наближатись до прийомів і методів, які застосовуються у навколишньому житті.

Уникаючи одноманітності та шаблону під час складання прикладних задач, вчителю необхідно використовувати різні формулювання умов, чітко виділяти описову частину, подавати умову задачі у вигляді короткого оповідання, задачі-розрахунки та ін.

Зауважимо, що задачі прикладного змісту не можуть утворювати самостійну дидактичну систему тих задач, які забезпечать необхідне закріплення всього теоретичного матеріалу, що вивчається на уроках математики.

Лише за дотримання таких вимог учителеві вдасться показати учням, що математика відображає навколишній світ, що числа, дії, математична термінологія мають реальний зміст. Це сприятиме не формальному вивченню учнями математики і привчатиме їх бачити у цій навчальній дисципліні спосіб дослідження питань економічного, екологічного, валеологічного, фінансового життя людей своєї країни.

\section{ЛІТЕРАТУРА}

1. Данилова Л. Розвивати пізнавальну активність учнів. Рідна школа, 2002. №6, С.1820.

2. Лозова В.І. (Цілісний підхід до формування пізнавальної активності школярів. Харків: ОВС. 2000.

3. Найдьонова О.О., Канакіна Л.П. Педагогічні функції прикладних задач. Математика, 2004. №3, C.12.

4. Романенко Л.3. Навчальна гра як засіб активізації пізнавальної діяльності на уроках у початкових класах. URL: $\underline{\text { http://www.slideshare.net/ }}$ tatyana6221310/ss-29723650

5. Савченко О.Я. Дидактика початкової школи: підручник для студентів педагогічних факультетів. Київ: Генеза. 2002. 368 с.

6. Федорова М.А. Пізнавальна активність як складова формування моральних цінностей в учнів початкових класів. Нові технології навчання. Науково-методичний збірник. Київ-Вінниця. 2011. №69, С.116-120.

7. Хилько Є.Є. Теоретичні аспекти навчальнопізнавальної діяльності особистості: рівні, компоненти. Вісник Черкаського університету. Серія: Педагогічні науки. 2011. (Випуск 203. Частина II), C.131 - 135.

\section{REFERENCES}

1. Danylova, L. (2002). Rozvyvaty piznavalnu aktyvnist uchniv [Develop students' cognitive activity]. Native school, Kyiv, Vol.6, pp. 18-20. [in Ukrainian].

2. Lozova, V.I. (2000). Tsilisnyi pidkhid do formuvannia piznavalnoi aktyvnosti shkoliariv [A holistic approach to the formation of cognitive activity of students]. Kharkiv. [in Ukrainian].

3. Naidonova, O.O. \& Kanakina, L.P. (2004). 


\section{ОГЛЯД ДЖЕРЕЛОЗНАВЧОЇ БАЗИ ДОСЛІДЖЕННЯ ПРОЦЕСУ ПІДГОТОВКИ ФАХІВЦІВ У МЕДИЧНИХ(ФАРМАЦЕВТИЧНИХ) ОСВІТНІХ ЗАКЛАДАХУКРАЇНИ}

Pedahohichni funktsii prykladnykh zadach [Pedagogical functions of applied tasks]. Mathematics, Kyiv, Vol. 3, p. 12. [in Ukrainian].

4. Romanenko, L.Z. Navchalna hra yak zasib aktyvizatsii piznavalnoi diialnosti na urokakh $\mathrm{u}$ pochatkovykh klasakh [Educational game as a means of activating cognitive activity in lessons in primary school]. Available at: http://www.slideshare.net/ tatyana6221310/ss-29723650. [in Ukrainian].

5. Savchenko, O.Ia. (2002). Dydaktyka pochatkovoi shkoly: pidruchnyk dlia studentiv pedahohichnykh fakultetiv [Primary school didactics: a textbook for students of pedagogical faculties]. Kyiv, 368 p. [in Ukrainian].
6. Fedorova, M.A. (2011). Piznavalna aktyvnist yak skladova formuvannia moralnykh tsinnostei $\mathrm{v}$ uchniv pochatkovykh klasiv [Cognitive activity as a component of the formation of moral values in primary school students]. New learning technologies. Scientific and methodical collection. Kyiv-Vinnytsia. Vol. 69, pp. 116-120. [in Ukrainian].

7. Khylko, Ye.Ie. (2011). Teoretychni aspekty navchalno-piznavalnoi diialnosti osobystosti: rivni, komponenty [Theoretical aspects of educational and cognitive activity of personality: levels, components]. Bulletin of Cherkasy University. Series: Pedagogical sciences. Vol. 203. Part II, pp. $131-$ 135. [in Ukrainian].

Стаття надійшла до редакції 24.12.2020

УДК 378(091):[61+615](477)

DOI:

Ірина Радзісвська, кандидат педагогічних наук, проректор з навчальної роботи Черкаської медичної академії

\section{ОГЛЯД ДЖЕРЕЛОЗНАВЧОЇ БАЗИ ДОСЛІДЖЕННЯ ПРОЦЕСУ ПІДГОТОВКИ ФАХІВЦІВ У МЕДИЧНИХ (ФАРМАЦЕВТИЧНИХ) ОСВІТНІХ ЗАКЛАДАХ УКРАЇНИ}

У статті подано аналіз історичних джерел дослідження теоретичних і практичних засад медичної $i$ фармацевтичної освіти молодших спеціалістів в Україні. Оскільки медична і фармацевтична освіта в Україні є складовою частиною загальної вітчизняної освітньої системи, особливості та специфіка навчання в медичних та фармацевтичних закладах освіти характеризуються з точки зору загальних закономірностей і тенденцій розвитку освіти в державі у різні періоди історії XX-початку XXI cm. Проведено огляд та опрацювання джерел з історії розвитку освіти - історико-педагогічної літератури та літератури з історії медицини та медичної освіти.

Ключові слова: медична та фармачевтична освіта; молодиі спечіалісти; історичні джерела; тендениї розвитку освіти.

Jim. 5.

Iryna Radzievska, Ph.D.(Pedagogy)

Vice Rector of Research work of Cherkasy Medical Academy

\section{REVIEW OF THE SOURCE BASE OF STUDYING THE PROCESS OF TRAININGSPECIALISTS INMEDICAL(PHARMACEUTICAL)EDUCATIONALINSTITUTIONS OF UKRAINE}

The necessity to improve the quality of education of medical specialists is emphasized in the law of Ukraine "On Higher Education", "National Strategy for the Education Development in Ukraine for 2012-2021", the Intersectoral Comprehensive Program "Health of the Nation", "Concepts for the Development of Public Health". It is especially true for the training of medical and pharmaceutical personnel, which is associated with the need to improve the quality of education in accordance with the requirements of modern practical medicine.

The concept of development of Public Health Protection of Ukraine provides for the implementation of innovative and personnel policy in the healthcare system: "improving the training system of medical and pharmaceutical specialists, developing and implementing educational standards in the educational process, broadening the functions of medical and pharmaceutical specialists in accordance with the world experience, which will reduce the demand for doctors and pharmacists in the State".

Investigating the trends in the development and reform of education of medical (pharmaceutical) workers, it is worth noting that the period of the XX-beginning of the XXI centuries is characterized by a new approach to the theory and practice of medical (pharmaceutical) education, the creation of a substantial base for scientific research, and it is worth noting that the education of junior specialists, its progress, improvement and development are not sufficiently studied in modern scientific literature. The analysis of historical and pedagogical research on the professional training of future doctors or pharmacists has shown that, in our opinion, it is worth thoroughly analyzing the experience of the "post-Soviet countries" that have a cultural and historical identity with Ukraine. 